Japan. J. Med. Sci. Biol., 21, 95-101, 1968

\title{
AINO VIRUS, A NEW MEMBER OF SIMBU GROUP OF ARBOVIRUS FROM MOSQUITOES IN JAPAN
}

\author{
KATSUMI TAKAHASHI*, AKIRA OYA**, TOSHIKO OKADA**, \\ REIZO MATSUO*, MASAAKI KUMA* AND HidetaRO NOGUCHI* \\ * Nagasaki Prefectural Institute of Public Health, Nagasaki, Japan \\ ** Department of Virology \& Rickettsiology, National Institute of Health, Tokyo
}

(Received : January 18th, 1968)

\begin{abstract}
SUMMARY: Three strains of non-Japanese encephalitis virus were isolated from mosquitoes caught in mid-September, 1964, in Aino town, Nagasaki prefecture, Japan. Two of them were recovered from pools of Culex tritaeniorhynchus and one from a mixed pool of Culex pipiens and Culex pseudovishnui. All of these viruses were shown to be fatal to the adult mouse by intracerebral inoculation, ether sensitive, inactivated by desoxycholate and not precipitated with protamine sulfate. These characteristics of the viruses, therefore, are in good accord with those of arbovirus.

Since viral hemagglutinin could not be detected by sucrose-aceton extraction of the infected suckling mouse brain, immunological identification of the viruses was achieved by the complement fixation test. As a result, these viruses were antigenically alike and furthermore turned out to be a new member of Simbu group of arbovirus. It is proposed to name this new virus Aino.

Later, in 1965 and 1966 attempts to reisolate the virus from mosquitoes collected in Nagasaki area were unsuccessful.
\end{abstract}

\section{INTRODUCTION}

As reported earlier (Takahashi et al., 1965), three strains of non-Japanese encephalitis virus were isolated from mosquitoes during the course of studies on the ecology of Japanese encephalitis (JE) virus in Nagasaki prefecture in the autumn of 1964. Identification studies hitherto undertaken revealed evidences that these viruses were antigenically alike and probably a new member of Simbu group of arbovirus. The purpose of the present paper is to report biological and immunological properties of this arbovirus.

\section{Materials AND MethodS}

Viruses: Three strains of viruses were examined. Two strains isolated from Culex tritaeniorhynchus were designated as JaNAr 28 and JaNAr 29 (Japan, Nagasaki, Arthropod-borne and No. of isolated strains). The remaining one isolated from a mixture of Culex pipiens and Culex pseudovishnui was designated as JaNAr 32. The prototype strains of Simbu group used for identification were kindly given by Dr. J. Casals, Yale Arbovirus Research Unit, U. S. A.. Virus titration was made by intracerebral inocu-

高橋 克巳・松尾 礼三・熊 正昭 - 野口英太郎 (長崎県衛生研究所)

大谷明・岡田 寿子(国立予防衛生研究所ウイルスリケッチア部) 
lation into 4-week-old mice, each of which received $0.02 \mathrm{ml}$ of virus suspension. Phosphate buffered saline ( $\mathrm{pH}$ 7.4) supplemented with $2 \%$ calf serum free of JE antibody was used as virus-diluent. Titration endpoint was determined by the method of Reed and Muench (1938).

Inactivation test with sodium desoxycholate: The technique used for the inactivation test with sodium desoxycholate (SDC) was described elswhere (Oya et al., 1961) following the original report described by Theiler (1957).

Sensitivity test with ether: Sensitivity test with ether was performed by the method of Sunaga, Taylor and Henderson (1960).

Precipitation test with protamine sulfate: Precipitation test with protamine sulfate was made as described by Oya et al. (1961).

Antigens: The sucrose-acetone-extracted antigens for the complement fixation $(\mathrm{CF})$ test and hemagglutination (HA) test were prepared from infected brains of 2-4 day old suckling mice in a manner simillar to that described by Clark and Casals (1958).

Antisera: Hyperimmune sera against each virus strain used for the CF test were prepared in adult mice with 4 to 5 intraperitoneal injections of living virus suspensions.

HA test: HA test was performed by a method slightly modified (Oya et al., 1961) from the original technique described by Clark and Casals (1958).

CF test: The minute amount method employing a Disposo-tray (Okuno et al., 1961) was employed.

\section{RESULTS}

\section{Isolation of Viruses}

Culex tritaeniorhynchus were collected in Aino area (Lat: $32^{\circ} 48^{\prime} \mathrm{N}$. Long: $130^{\circ}$ $9^{\prime}$ E.), Nagasaki prefecture, in 1964.

In that year, mosquito infection with JE virus was observed earlier in the season. As shown in Fig. 1 the first isolation of $\mathrm{JE}$ virus from the mosquito was made on May 19 and the last one on July 6. After that no virus was detected until early September even though a great many mosquitoes were tested for virus isolation. Suddenly in mid-September, however, two strains of non-JE virus (JaNAr 28 and JaNAr 29) were isolated from among 1,237 female Culex tritaeniorhynchus in 6 pools, which were collected on September 14. On the other hand, one strain of virus (JaNAr 32) was isolated form a mixed pool of 96 female Culex pipiens and 126 female Culex pseudovishnui collected both during the period from July 27 to September 14. Therefore, the collection date and the species of mosquito infected with JaNAr 32 are not clear. However, considering the fact that JaNAr 28 and JaNAr 29 were isolated only from the Culex tritaeniorhynchus collected on September 14, it seems reasonable to assume that JaNAr 32 also may have come from the mosquitoes collected around September 14. These 3 strains were found to have no immunological relation with $\mathrm{JE}$ virus as shown by the CF test. Finally, a total of 27,230 female mosquitoes of 6 species (Culex tritaeniorhynchus, Culex pipiens, Culex pseudovishnui, Culex bitaeniorhynchus, Anopheles sinensis and Armigeres subalbatus) in 201 pools were tested for virus isolation in 1964 and consequently three strains of non-JE virus and 30 strains of $\mathrm{JE}$ virus were isolated.

In 1965, a total of 38,445 female Culex tritaeniorhynchus in 402 pools collected in Aino (Takahashi et al., 1966) and in 1966, a total of 183,571 female Culex tritaenior- 


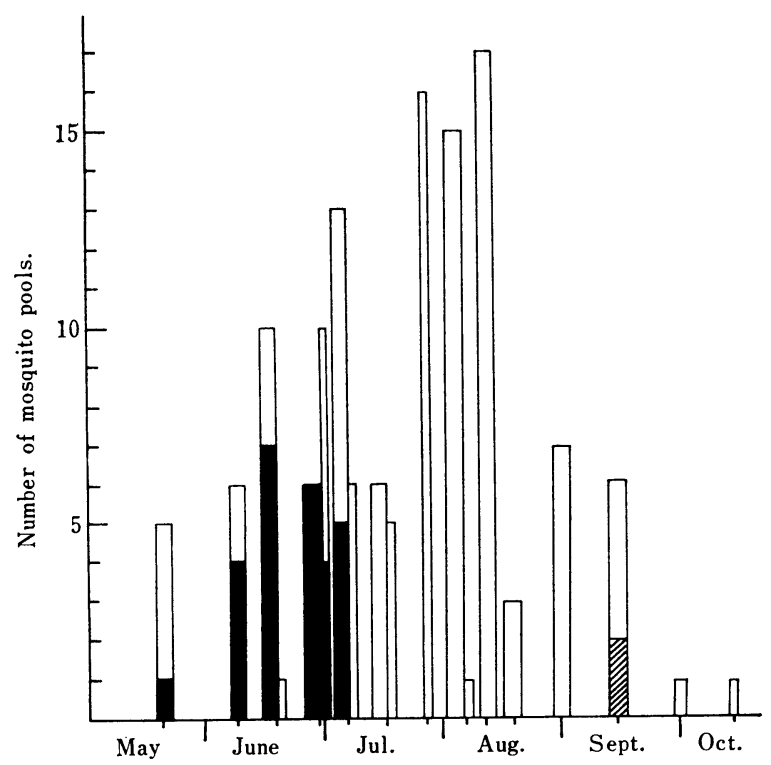

Fig. 1. Isolation of Japanese encephalitis virus and non-Japanese encephalitis virus from female Culex tritaeniorhynchus collected in Aino, Nagasaki prefecture, in 1964.

The solid parts of columns show the number of the mosquito pools yielded Japanese encephalitis virus. The obliquely lined part shows the mosquito pools yielded non-Japanese encephalitis virus.

—... Pools containing approximately 100 mosquitoes.

$\square \ldots$ Pools containing approximately 200 mosquitoes.

hynchus in 942 pools collected at 11 places including Aino, in the southern area of Nagasaki prefecture, were tested but attempts to reisolate non-JE virus from those mosquitoes were unsuccessful.

\section{Biological Properties}

All of the three strains of non-JE virus killed adult mice and suckling mice by i. c. inoculation but not by the intraperitoneal route. The minimum incubation period was 2 days with suckling mice and 3 days with adult mice. The maximum titer $\left(\mathrm{LD}_{50} /\right.$ $0.02 \mathrm{ml}$ ) reached $10^{8.2}$ with suckling mice and $10^{7.5}$ with adult mice. In comparison of $\mathrm{LD}_{50}$ between the supernatant of emulsion of mouse brain infected with JaNAr 28 strain centrifuged at $10,000 \mathrm{rpm}$ for 30 minutes and that centrifuged at $3,000 \mathrm{rpm}$ for 30 minutes, no significant differences was noted.

As listed in Table 1, JaNAr 28 strain was shown to be ether sensitive, inactivated with SDC and not precipitated with protamine sulfate. Those properties of virus, therefore, were assumed to be in good accordance with those of arbovirus. Attempts to detect viral hemagglutination from suckling mouse brains infected with each strain of the virus either by the ether-aceton method or by the sucrose-aceton method (Clarke and Casals, 1958) were unsuccessful even at $1: 10$ dilution of the extract at various pHs from 6.0 to 7.0. Following the example of Akabane virus (Oya et al., 1961), terminal dilution passages through suckling mouse brains were done and at the 15th 
Table 1. Effects of ether, sodium desoxycholate and protamine sulfate treatment on the infectivity of JaNAr 28

\begin{tabular}{lcc}
\hline \multirow{2}{*}{ Treatment } & \multicolumn{2}{c}{ Titer as $\log \mathrm{LD}_{50} / 0.02 \mathrm{ml}$} \\
\cline { 2 - 3 } & Treated & Control \\
\hline Ether & 1.4 & 6.0 \\
Sodium desoxycholate & $<4.0$ & 7.0 \\
Protamine sulfate & 7.3 & 7.5 \\
\hline
\end{tabular}

passages level antigens were prepared by the sucrose-acetone method, but the result remained unchanged. Therefore immunological identification was done by the CF test.

\section{Immunological Approaches}

The biological properties of these viruses seemed similar to those of Akabane virus, especially in that the virus showed a high virulence for adult mice with a short incubation period. Akabane virus, which belongs to Simbu group of arbovirus, was isolated in 1959 in Kanto plane, in Japan (Oya et al., 1961). Therefore, identification studies were focused to examine whether these viruses were immunologically related with each other. A cross CF test was made among Akabane, JaNAr 28, JaNAr 29 and JaNAr 32.

As can be seen in Table 2, the result of the cross CF test definitely showed that these three strains of non-JE virus were antigenically identical and were related to each other, but not identical to Akabane. However, it became definite that all viruses examined belonged to the same group Simbu.

Table 2. Cross complement fixation tests with JaNAr 28, JaNAr 29, JaNAr 32 and Akabane viruses

\begin{tabular}{ccc}
\hline & \multicolumn{2}{c}{ Sera } \\
\cline { 2 - 3 } SAFD $^{* *}$ & $\begin{array}{c}\text { Akabane } \\
\text { inj. m. s. }\end{array}$ & $\begin{array}{c}\text { JaNAr 28 } \\
5 \text { inj. m. s. }\end{array}$ \\
\hline Akabane & $64 / 256^{* * *}$ & $16 / 512^{+}$ \\
JaNAr 28 & $16 / 256$ & $64 / 512^{+}$ \\
JaNAr 29 & $32 / 512^{+}$ & $64 / 512^{+}$ \\
JaNAr 32 & $16 / 512^{+}$ & $64 / 512^{+}$ \\
Normal mouse brain & $0 / 0$ & $0 / 0$ \\
\hline
\end{tabular}

* Five injection mouse immune serum.

** Suckling mouse brain antigen treated by sucrose-acetone, frozen and dried.

*** Numerator means serum titer, and denominator antigen titer; plus means endpoint beyond the titer described and 0 under $1: 4$.

In order to learn the immunological relationship of JaNAr 28 to members of the Simbu group already described (Sub-Commitee on Information Exchange of the American Commitee on Arthropod-Borne Viruses, 1965), cross CF tests were performed with the following viruses: Akabane, JaNAr 28, Sathuperi, Oropouche, Simbu, Manzanilla and Ingwavuma. 
As shown in Table 3, seven viruses are more or less related to each other. It seems also evident that Akabane, JaNAr 28, Sathuperi and Simbu are in closer relation being a little apart from the other 3 viruses. However, the antigenic make-up of JaNAr 28 appears to be distinct from Akabane, Sathuperi and Simbu as Akabane differs from the other 3 viruses. Taking account of those facts, JaNAr 28 (prototype of 3 strains) is finally considered to be listed as a new member of the Simbu group of arbovirus. It may be called as Aino virus taking the name of the town where the virus was isolated.

Table 3. Cross-complement fixation tests among JaNAr 28 and representative Simbu group arboviruses

\begin{tabular}{|c|c|c|c|c|c|c|c|}
\hline \multirow[b]{2}{*}{$\begin{array}{l}\text { Antigen } \\
\text { SAFD }^{* *}\end{array}$} & \multicolumn{7}{|c|}{ Serum } \\
\hline & $\begin{array}{c}\text { JaNAr } 28 \\
5 \text { inj. }{ }^{*}\end{array}$ & $\begin{array}{c}\text { Akabane } \\
5 \text { inj. }\end{array}$ & $\begin{array}{l}\text { Simbu } \\
4 \text { inj. }\end{array}$ & $\begin{array}{l}\text { Sathuperi } \\
4 \text { inj. }\end{array}$ & $\begin{array}{l}\text { Oro- } \\
\text { pouche } \\
4 \text { inj. }\end{array}$ & $\begin{array}{l}\text { Ingwa- } \\
\text { vuma } \\
4 \text { inj. }\end{array}$ & $\begin{array}{c}\text { Manza- } \\
\text { nilla } \\
4 \text { inj. }\end{array}$ \\
\hline JaNAr 28 & $64 / 256$ & $8 / 128$ & $32 / 256$ & $32 / 64$ & $4 / 64$ & $4 / 4$ & $0 / 0$ \\
\hline Akabane & $16 / 512$ & $64 / 512$ & $32 / 256$ & $16 / 128$ & $4 / 256$ & $4 / 4$ & $8 / 128$ \\
\hline Simbu & $16 / 512$ & $32 / 256$ & $128 / 256$ & $32 / 256$ & $8 / 256$ & $4 / 128$ & $0 / 0$ \\
\hline Sathuperi & $16 / 512$ & $32 / 512$ & $32 / 512$ & $128 / 512$ & $8 / 1,024$ & $4 / 8$ & $0 / 0$ \\
\hline Oropouche & $0 / 0$ & $8 / 128$ & $16 / 256$ & $4 / 64$ & $128 / 1,024$ & $16 / 512$ & $16 / 512$ \\
\hline Ingwavuma & $0 / 0$ & $0 / 0$ & $0 / 0$ & $0 / 0$ & $4 / 128$ & $128 / 512$ & $16 / 1,024$ \\
\hline Manzanilla & $0 / 0$ & $0 / 0$ & $0 / 0$ & $0 / 0$ & $8 / 256$ & $16 / 1,024$ & $256 / 512$ \\
\hline $\begin{array}{l}\text { Normal } \\
\text { mouse brain }\end{array}$ & $0 / 0$ & $0 / 0$ & $0 / 0$ & $0 / 0$ & $0 / 0$ & $0 / 0$ & $0 / 0$ \\
\hline
\end{tabular}

Numerator means serum titer and denominator antigen titer.

* Five injection serum.

** Suckling mouse brain antigen treated by sucrose-aceton and freeze-dried.

\section{DISCUSSION}

An extensive survey of mosquito infection with arboviruses in Nagasaki, Kyushu, a southern part of Japan was initiated by the authors at the Nagasaki Prefectural Institute of Health in 1964. A number of JE virus strains has been isolated so far in the epidemic season every year (Takahashi et al., 1956, 1966). However, arbovirus other than JE virus seldom has been isolated even though more than ten thousand mosquitoes were examined every year. Only 3 strains of non-JE virus were isolated in 1964 in the survey covering 3 years from 1964 to 1966 . Evidences are presented in this report to identify these viruses as a member of the Simbu group. Cross CF tests showed that JaNAr 28 virus was not identical with any other member of the Simbu group so far tested. Buttonwillow virus isolated by Reeves in 1964 at Kern County, California, U. S. A. was not included in the present investigation though it has been listed as a member of the Simbu group. However, it may probably be distinct from JaNAr 28 as it cross-reacts highly with Ingwavuma. Therefore, Aino virus is considered to be a new member of the Simbu group.

It should be pointed out that two immunological subgroups appeared to be present in our cross CF test shown in Table 3. The trend may be more clearly demonstrated 
when $\mathrm{CF}$ patterns are figured out as in Fig. 2. One subgroup may be designated as Asian type including Akabane (Japan), Aino (Japan), Sathuperi (India), Simbu (Africa) and the other as American type composed of Oropouche (Brazil and Trinidad), Manzanilla (Trinidad) and Ingwavuma (Africa). The fact that the distribution of these two types is overlapping in Africa might suggest the origin of these viruses being in Africa.

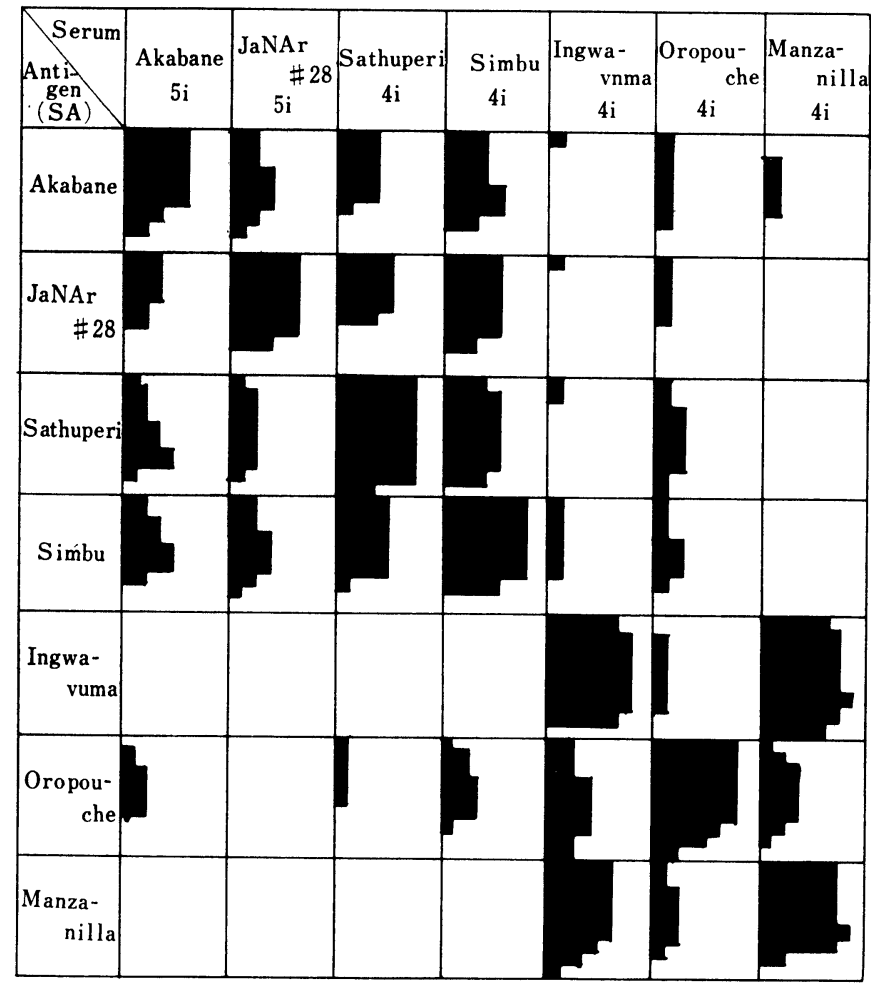

Fig. 2. Immunological relationships among members of Simbu group arbovirus and newly isolated JaNAr 28 in complement fixation test.

Absissa and ordinate of each square denote dilution of antiserum and antigen respectively, the upper-left corner representing $1: 4$ and lowerright, 1:512 dilution. More than $75 \%$ of fixation was shadowed in each square.

SA $\cdots$. Suckling mouse brain antigen treated by sucrose-aceton, frozen and dried.

5i $\cdots$. Five injection mouse serum.

As for the ecology of the Simbu group viruses in Japan, it is worth noting that Akabane virus was isolated first in 1959, as many as 6 strains being obtained in the Kanto plain (Oya et al., 1961) and not thereafter until 1966. Three strains of Aino virus were isolated in Nagasaki in 1964 but never thereafter. It is quite conceivable that these viruses might be introduced from somewhere outside of Japan, but never overwintered. The way in which they were introduced to Japan has remained obscure, but migratory birds should be reasonably suspected to have played a role. 


\section{ACKNOWLEDGEMENTS}

The authors wish to express their gratitude to Yale Arbovirus Research Unit, U. S. A. for their kind supply of prototype strains of arbovirus. Thanks are also due to Dr. Takeshi Okuno, WHO medical officer in Taipei for his helpful advice.

\section{REFERENCES}

Clarke, D. H. AND CASAls, J. (1958): Techniques for hemagglutination and hemagglutination-inhibition with arthropod-borne viruses. Am. J. Trop. Med. Hyg., 7, 561-573.

Fulton, F. AND Dumbell, K. R. (1949): The serological comparison of the strains of influenza virus. J. Gen. Microbiol., 3, 97-111.

Matsuyama, T., Oya, A., Ogata, T., Kobayashi, I., Nakamura, T., Takahashi, M. AND KITAOKA, M. (1960): Isolation of arbor viruses from mosquitoes collected at livestock pens in Gumma prefecture in 1956. Japan. J. Med. Sci. Biol., 13, 191-198.

OKuno, T., OYA, A. AND ITO, T. (1961): The identification of Negishi virus. A presumably new member of Russian spring-summer encephalitis virus familly isolated in Japan. Japan. J. Med. Sci. Biol., 14, 51-59.

Oya, A., Okuno, T., Ogata, T., Kobayashi, I. And Matsuyama, T. (1961): Akabane, a new arbor virus isolated in Japan. Japan. J. Med. Sci. Biol., 14, 101-108.

REED. L. J. AND MUENCH, H. (1938): A simple method of estimating fifty per cent endpoint. Am. J. Hyg., 27, 493-497.

Scherer, W. F., Funkenbush, M., Buescher, E. L. AND IzumI, T. (1962) : Sagiyama virus, a new arthropod-borne virus from Japan. I. Isolation, immunologic classification and ecologic observation. Am. J. Trop. Med. Hyg., 11, 255-268.

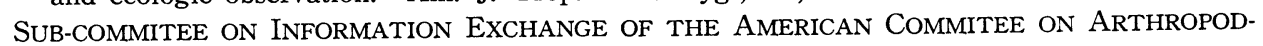
BORNE VIRUSES. (1965): Catalogue of arbovirus.

Sunaga, H., TAYloR, R. M. AND Henderson, J. R. (1960): Comparative sensitivity of viruses to treatment with diethyl ether and sodium desoxycholate. Am. J. Trop. Med. Hyg., 9, 419-424.

Takahashi, K., Matsuo, R., Kuma, M. And Noguchl, H. (1965): Studies on mosquito infection with Japanese encephalitis virus in 1964, in Nagasaki Prefecture. End. Dis. Bull. Nagasaki., 7, 165-177.

Takahashi, K., Matsuo, R., Kuma, M., Noguchi, H. and Higashi, F. (1966) : Epidemiological studies on Japanese encephalitis in Nagasaki prefecture in the 1965 season. I. Isolation of Japanese encephalitis virus from Culex tritaeniorhynchus collected in Aino, Nagasaki prefecture in 1965 . End. Dis. Bull. Nagasaki, 8, 1-7.

THEILER, M. (1957) : Action of sodium desoxycholate on arthropod-borne viruses. Proc. Soc. Exptl. Biol. Med., 96, 380-382.

Warren, J., Well, M. L., Russ, S. B. AND Jeffries, H. (1949): Purification of certain viruses by use of protamine sulfate. Proc. Soc. Exptl. Biol. Med., 72, 662-664. 